\title{
THE ERRORS IN VISUAL ESTIMATION OF PLANTS COVER IN THE CONTEXT OF EDUCATION OF PHYTOSOCIOLOGY
}

\author{
BLĘDY W OSZACOWANIU POKRYCIA ROŚLIN \\ W KONTEKŚCIE NAUCZANIA FITOSOCJOLOGII
}

\begin{abstract}
In vegetation science including phytosociology, visual estimates of plant cover and point method belong to the common field method to record species composition and their abundance. Two methods were compared: Braun-Blanquet scale and point method using Levy bridge. A group of students performed measurements in five plots belonged to an oak-hornbeam forest Tilio-Carpinetum. It was revealed that there is a very high discrepancy in a observed number of species. Total mean numbers obtained are 13.4 and 31.2 for point method and Braun-Blanquet method respectively. However, there is the significant positive and medium correlation between two methods in terms of estimation of abundance of species. It can be concluded that point-method is not suitable for study of forest floor vegetation. It can be merged with other methods. Due to many repetitive measures, it can be helpful in learning of recognition of species.
\end{abstract}

Keywords: ocular estimates of cover, sampling error, species pseudoturnover

\section{Introduction}

A lot of methods of botanical field research aiming at quantitatively assessing of species abundance in plant communities are available [1]. They can be divided into three groups: frequency techniques, visual estimates methods and estimation of relative biomass. The first two methods are not invasive and are relatively fast, cheap and easy to use. The example of frequency techniques are quadrate method, when the quadrate of size e.g. $0.1 \mathrm{~m} \cdot 0.1 \mathrm{~m}$ is being randomly placed within a plot several times. The frequency of records of particular species was a measure of its abundance. The results were expressed as the percent frequency. Other methods that belong to a group of frequency techniques are so called point methods. These are the Levy bridge, the wheel point [2] and the steep point [3]. These methods consist of the use of dimensionless points instead of the quadrate. The special device or rod is being used to touch randomly plants in a plot or the plant species nearest to the point are recorded. These point methods differ in the distance between successive points. They mainly measure proportional abundance then cover of species [1].

\footnotetext{
${ }^{1}$ Institute of Environmental Protection and Engineering, University of Bielsko-Biala, ul. Willowa 2, 43-309 Bielsko-Biała, Poland, phone +48 338279185 , fax +48 338279101

* Corresponding author: dchmura@ath.bielsko.pl
} 
Amongst visual estimates methods Braun-Blanquet scale [4] is the most popular. It is commonly applied in phytosociology. This scale is suitable for synmorphological and syntaxonomical purposes, but its intervals are as a rule too broad for the study of a community [5]. Braun-Blanquet scale is the 7-degree scale and there are a lot of the scale transformations [6-8]. Apart from Braun-Blanquet scale there are other scales applied in vegetation science: e.g. 11-degree Domin scale [9, 10], 10-degree Doing-Kraft [11]. All of the visual estimates methods rely on cover that is determined from estimates of vertical plant shoot-area projection as a percentage of quadrat area. These methods are often criticised for their subjectivity that can results in sampling error, difficult to control $[12,13]$.

The third group of methods is techniques associated with estimation of relative biomass. In this method, a quadrat is randomly placed on the site. All species are recorded and in next step, they are removed and weighted. Later, the species are ranked based on their dry mass. We decided to choose one method that represents point-method and one of visual estimate method. We focused on the comparison of point-method using Levy bridge with visual estimates of species in herb layer using Braun-Blanquet approach. The use of Levy bridge was recommended to Polish students in the handbook by Gorecki et al. [14], whereas Braun-Blanquet scale of visual estimates is commonly applied a method in phytosociology, popular branch in vegetation science. We wanted to check what are pros and cons of the usefulness of both methods in the teaching of community ecology and field botany.

\section{Material and methods}

In five plots $(10 \mathrm{~m} \cdot 10 \mathrm{~m})$ in oak-hornbeam forest Tilio-Carpinetum in Szymbark group of students evaluated cover-abundance of species in herb layer using Braun-Blanquet scale and using point method by Levy point sampler (Levy bridge) [2] (Fig. 1).

The frame is set up over the vegetation and the needles are lowered down through the plant canopy. Every time the point of a needle touches a plant, a "touch" is recorded with the species name. There are 10 holes and a frame is randomly set 10 times within a plot thus a plant can be touched maximum 100 times. Number of touches is regarded as a species frequency according to the formula:

$\%$ cover of species $\mathrm{A}=$ (No. of points that intercept species $\mathrm{A}$ at least once) ${ }^{\text {. }}$ $100 \% /$ Total number of points.

As Braun-Blanquet scale is concerned the traditional version was applied i.e. 7-degree scale:

5 - (100-75\% of cover), 4 - (75-50), 3 - (50-25), 2 - (25-5), $1-(5-1),+-(<1 \%)$, $\mathrm{r}$ - single occurrence of plants of particular species.

In order to compare methods in terms of species composition nonmetricmultidimensional scaling was run (package vegan) $[15,16]$. Bray-Curtis dissimilarity was used as distance. No cover of species was included in this analysis because it would be hard to standardise them. Therefore only presence/absence data were taken into consideration. Two groups of plots belonging to two methods of estimation were visualised on a plot.

The three dissimilarities accounting for the spatial turnover and the nestedness components of beta diversity, and the sum of both values were calculated using package betapart [17, 18]. The value of the turnover component was measured as Simpson dissimilarity. The nestedness component was a fraction of Sorensen dissimilarity. Sorensen 
dissimilarity was treated as the overall beta-diversity. All statistics were computed per pair of methods on the site.

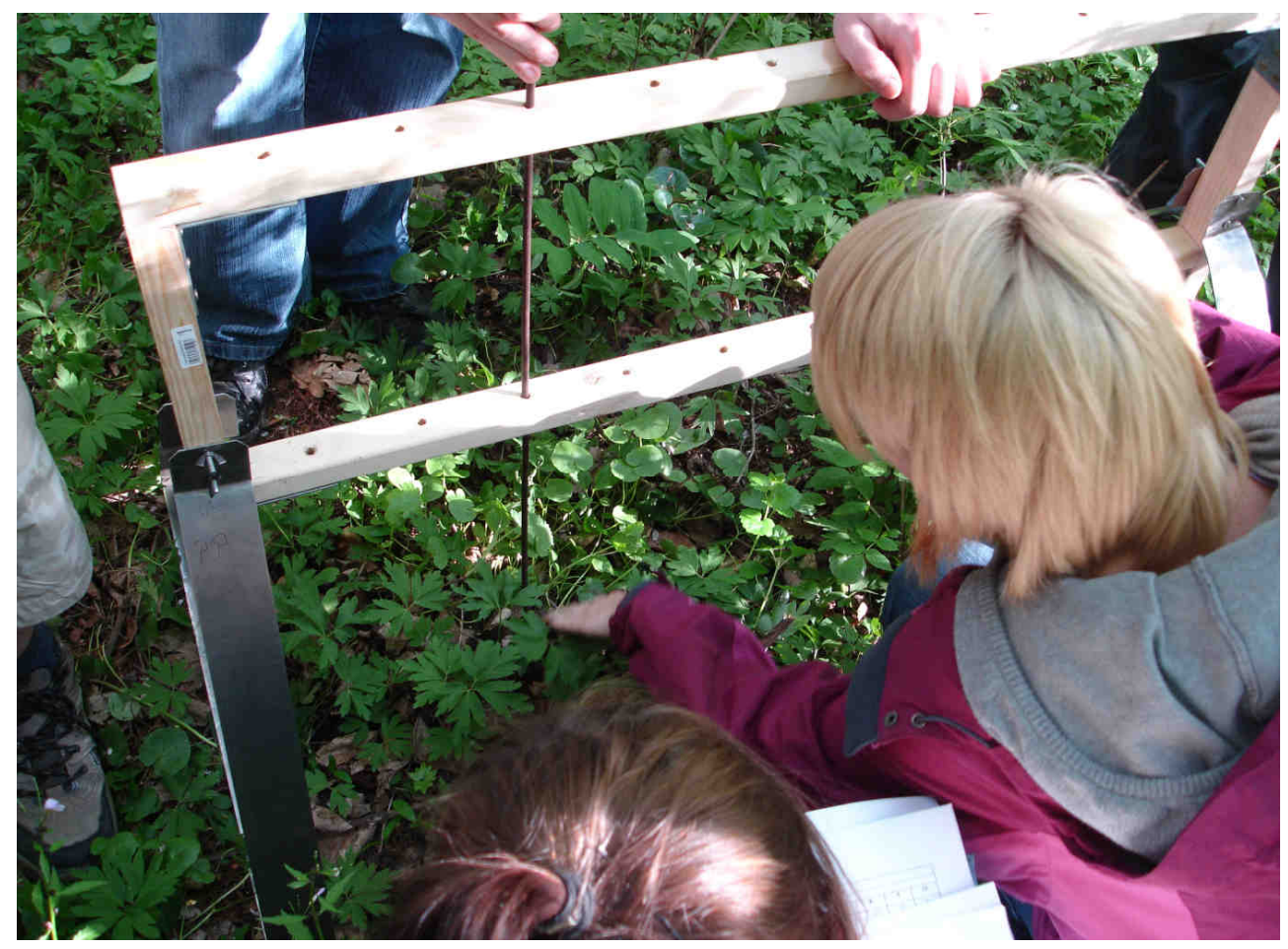

Fig. 1. Student working with Levy bridge - wooden frame with ten holes designed to estimate plant abundance

Pseudospecies turnover, expressed in \%, was computed but in this analysis cumulative number of species recorded from two methods per a site was regarded as the total reference number of species. Moreover, a total number of species, exclusive number of species per a method and per a site and common number of species per a site were counted. When pseudoturnover is equal 0 that means that all species from reference number of species were noted. The pseudoturnovers were calculated per a method in a site i.e. in total 10 calculations were made. Differences in frequency of species between two methods were assessed by Wilcoxon-paired test.

\section{Results}

The composition of plots differed significantly based on presence/absence data of species recorded between two methods in NMDS (Fig. 2). The plots that species composition was recorded by Braun-Blanquet method are located close the beginning of the first axis NMDS1, whereas plots recorded by point method are situated closer to the end of this axis. 


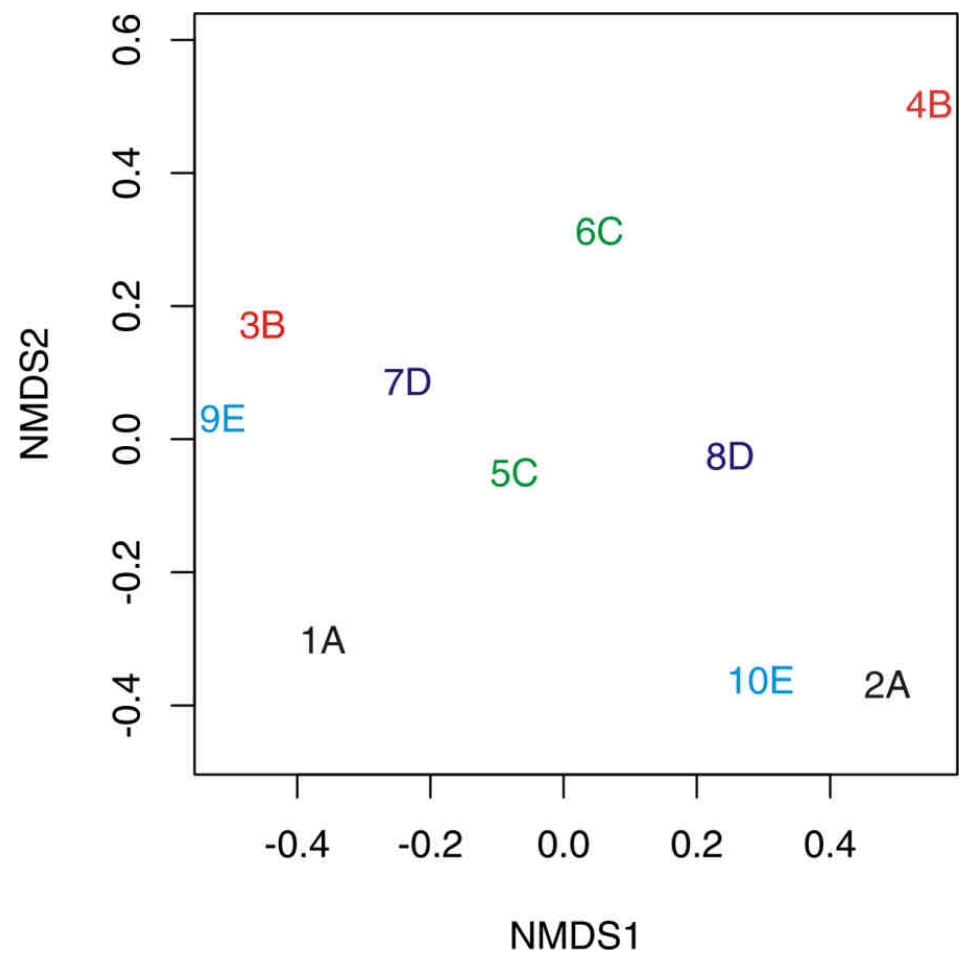

Fig. 2. Plot of sites (A-E) of Nonmetric Multidimensional Scaling Analysis (NMDS) based on presence/absence data in herb layer estimated by Braun-Blanquet scale (even numbers) and point method (odd numbers)

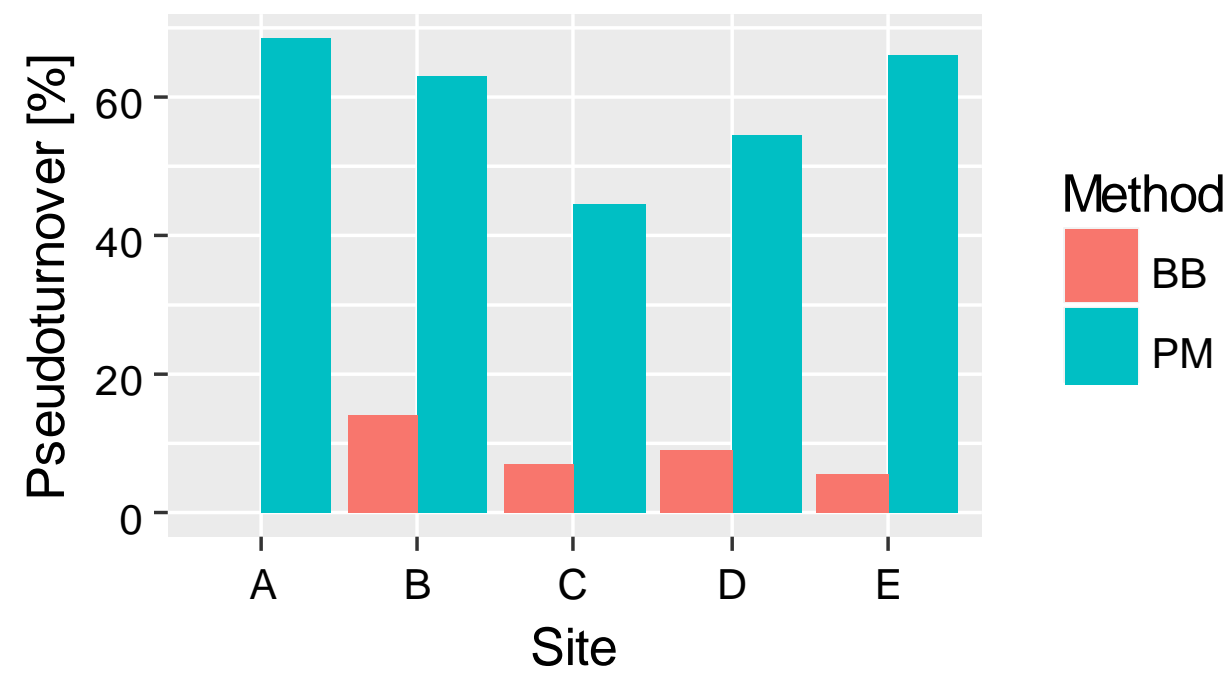

Fig. 3. Comparison of pseudoturnovers [\%] of species between Braun-Blanquet (BB) method and point method (PM) in five plots in oak-hornbeam forest Tilio-Carpinetum 
Turnover varied between 0 to 0.38 , whereas nestedness from 0.21 to 0.52 . The highest value was obtained in the site where turnover was 0 . Total dissimilarity ranged from 0.35 to 0.63. There is a high pseudoturnover of species between two methods (Table 1), however, the higher psedoturnover was revealed in point method (Fig. 3).

Table 1

Comparison of species replacement (turnover), species loss (nestedness) and total dissimilarity (expressed as Sorensen index) between Braun-Blanquet method and point method. BB total - total number of species found in Braun-Blanuet method, PM - total number of species found in point method

\begin{tabular}{|c|c|c|c|c|c|}
\hline & A & B & C & D & E \\
\hline BB total & 38 & 30 & 25 & 30 & 33 \\
\hline PM total & 12 & 13 & 15 & 15 & 12 \\
\hline Cumulative species richness & 38 & 35 & 27 & 33 & 35 \\
\hline Turnover & 0 & 0.38 & 0.13 & 0.2 & 0.16 \\
\hline Nestedness & 0.52 & 0.24 & 0.21 & 0.26 & 0.38 \\
\hline Total dissimilarity & 0.52 & 0.63 & 0.35 & 0.47 & 0.56 \\
\hline
\end{tabular}

On the average, there are 4.4 exclusive species in point method, whereas in Braun-Blanquet is 20.2. Total mean numbers obtained are 13.4 and 31.2 respectively. Only in one site using method (Braun-Blanquet) enabled to record all present species. In total 41 species were observed from all plots, wherein in Braun-Blanquet it was 40 whereas in point method - 23 species (Table 2). The frequency of species differed significantly between two methods $(V=30, p$-value $<0.0001)$, however, there is positive medium correlation between overall abundance within entire community expressed by frequency of species between the Braun-Blanquet scale and the point method $(r s=0.53, p<0.001)$.

Table 2

Frequency and minimum and maximum values of non-zero cover-abundance of total vascular plant species found using Braun-Blanquet (BB) and point-method (PM)

\begin{tabular}{|c|c|c|c|c|c|c|}
\hline & BB & MIN & MAX & PM & MIN & MAX \\
\hline Acer campestre & 4 & 0.1 & 0.5 & 3 & 1 & 7 \\
\hline Acer platanoides & 3 & 0.5 & 0.5 & - & - & - \\
\hline Acer pseudoplatanus & 3 & 17.5 & 17.5 & - & - & - \\
\hline Actacea spicata & 3 & 0.5 & 0.5 & - & - & - \\
\hline Aeogopodium podagraria & 3 & 0.5 & 17.5 & 2 & 2 & 35 \\
\hline Anemone nemorosa & 5 & 0.5 & 87.5 & 5 & 52 & 99 \\
\hline Asarum europaeum & 5 & 5 & 17.5 & 5 & 1 & 12 \\
\hline Carex sylvatica & 1 & 0.5 & 0.5 & 1 & 3 & 3 \\
\hline Carpinus betulus & 3 & 0.5 & 5 & - & - & - \\
\hline Chaerophyllum aromaticum & 1 & 0.5 & 0.5 & - & - & - \\
\hline Corylus avellana & 1 & 0.5 & 0.5 & - & - & - \\
\hline Crataegus monogyna & 1 & 0.5 & 0.5 & - & - & - \\
\hline Dentaria bulbifera & 5 & 5 & 37.5 & 4 & 2 & 20 \\
\hline Dentaria glandulosa & 3 & 0.1 & 5 & 4 & 5 & 22 \\
\hline Dryopteris filix-mas & 2 & 0.1 & 0.1 & - & - & - \\
\hline Evonymus europaeus & 3 & 0.1 & 0.5 & 2 & 2 & 2 \\
\hline Fagus sylvatica & 2 & 0.5 & 0.5 & - & - & - \\
\hline Ficaria verna & 3 & 0.5 & 37.5 & 3 & 1 & 3 \\
\hline Fraxinus excelsior & 3 & 5 & 17.5 & - & - & - \\
\hline Galeobdolon luteum & 4 & 0.5 & 5 & 4 & 1 & 7 \\
\hline Glechoma hederacea & 4 & 0.5 & 37.5 & 2 & 2 & 3 \\
\hline Lathyrus vernus & & - & - & 1 & 3 & 3 \\
\hline
\end{tabular}




\begin{tabular}{|c|c|c|c|c|c|c|}
\hline & BB & MIN & MAX & PM & MIN & MAX \\
\hline Lonicera xylosteum & 1 & 0.1 & 0.1 & - & - & - \\
\hline Maianthemum bifolium & 3 & 0.5 & 5 & 1 & 3 & 3 \\
\hline Mercurialis perennis & 1 & 17.5 & 17.5 & 2 & 6 & 35 \\
\hline Oxalis acetosella & 4 & 5 & 37.5 & 2 & 7 & 10 \\
\hline Padus avium & 2 & 0.1 & 0.5 & - & - & - \\
\hline Paris quadrifolia & 4 & 0.1 & 5 & - & - & - \\
\hline Picea abies & 2 & 0.1 & 0.1 & - & - & - \\
\hline Pinus sylvestris & 1 & 0.1 & 0.1 & - & - & - \\
\hline Polygonatum verticillatum & 5 & 17.5 & 37.5 & 5 & 5 & 15 \\
\hline Primula elatior & 5 & 0.5 & 17.5 & 1 & 5 & 5 \\
\hline Pulmonaria obscura & 5 & 5 & 5 & 3 & 2 & 5 \\
\hline Quercus robur & 3 & 0.1 & 0.1 & - & - & - \\
\hline Ranunculus cassubicus & 5 & 0.5 & 17.5 & 3 & 1 & 5 \\
\hline Rubus caesius & 4 & 0.5 & 5 & - & - & - \\
\hline Salvia glutinosa & 5 & 0.5 & 17.5 & 1 & 1 & 1 \\
\hline Sambucus nigra & 2 & 0.5 & 0.5 & 2 & 2 & 17 \\
\hline Sorbus aucuparia & 3 & 0.1 & 0.1 & - & - & - \\
\hline Tilia cordata & 3 & 0.5 & 5 & 2 & 1 & 1 \\
\hline Viola reichenbachiana & 2 & 0.5 & 0.5 & 3 & 1 & 2 \\
\hline
\end{tabular}

In almost all sites there are positive correlations between Braun-Blanquet estimates and frequency of point method (Table 3).

Correlation between cover-abundance estimated by Braun-Blanquet method and method

\begin{tabular}{|c|c|c|}
\hline Site & $r s$ & $p$ \\
\hline A & 0.47 & 0.0003483 \\
\hline B & 0.26 & NS \\
\hline C & 0.62 & $<0.0001$ \\
\hline D & 0.45 & 0.0006585 \\
\hline E & 0.34 & 0.01213 \\
\hline
\end{tabular}

\section{Discussion}

Results obtained showed huge differences between two methods. The number of species resulted from the estimation both in total and in each of plots was lower in the case of point method. We had expected that in terms of species composition samples estimated from two methods would be more similar to each other than to the remaining plots. However, according to NMDS analysis, there is a distinct gradient in species poverty along the first axis. All Braun-Blanquet plots are located closer to each other in one group while all point method plots in another group. The difference in species number is the most striking result in this study. One of the flaws of point-method, especially Levy bridge is the distance between successive points. It makes observations not independent [1]. In fact, this is the example of autocorrelation within the plant community [19] or even pseudoreplication sensu Hurlbert [20]. It is highly probable that plants of the same species can grow within small patch where Levy bridge is put in the plot. In very heterogeneous patch of vegetation where clumps of different species grow there is a risk that many species can be missed. Forest floor usually is very heterogeneous. Apart from mineral soil, leaf litter, humus, mobile wood, there are hummocks and cavities in the ground differing in moisture $[21,22]$. All of them can be occupied by different species. In turn, in grassland 
vegetation including meadows, xerothermic grasslands, pastures point method can be consistent. Originally Levy bridge was invented to estimate species composition and abundance of species in pasture vegetation [23]. Both methods are consistent in the estimation of abundance of species what was shown by the correlation between two methods in particular plots. The nearest plant technique and proportional species composition estimation belong to point methods [1], whereas visual estimate cover can resemble measuring frequency. The latter is not a random process and must encompass the whole area covered by vegetation in the plot. Thus, almost all species could be found in Braun-Blanquet method. We can conclude that in this form point method using Levy bridge is not suitable for conditions of forest vegetation. This method can give good and reasonable results if it is accompanied by a recording of all species present. After that in next step Levy bridge should be put randomly ten or more times within the plot in order to make estimations of species abundance.

Despite the higher discrepancies in the recording of species richness the point method by Levy and Madden [2] has some advantage in the education of phytosociology and field botany. Namely, common and rather common plant species in the plot can be touched many times. Students repeating measures can learn the look of specific plant species and can learn how to determine it in the field conditions.

Some point-methods are better in an estimation of other vegetation parameters. One of such method is the application of canopyscope that is used to estimate tree canopy. Several experiments admittedly showed higher objectivity and repeatability among observers of the method $[24,25]$.

\section{Conclusions}

Undoubtedly Levy bridge is not suitable for forest phytocoenoses due to the omission of many species. As the measure of a cover of species, it gives similar results to Braun-Blanquet. It can assist in recognising many forest herbs. The method can be used only with a combination of other methods e.g. count-list.

\section{References}

[1] Everson CS, Clarke GPY. A comparison of six methods of botanical analysis in the montane grasslands of Natal. Vegetatio. 1987;73(1):47-51. DOI: 10.1007/BF00031850.

[2] Griffin GF. An enhanced wheel-point method for assessing cover, structure and heterogeneity in plant communities. J Range Manage Arch. 1989;42(1):79-81. https://journals.uair.arizona.edu/index.php/ jrm/article/viewFile/4810/4421.

[3] Evans RA, Love RM. The step-point method of sampling-a practical tool in range research. J Range Manage Arch. 1957;10(5):208-212. https://journals.uair.arizona.edu/index.php/jrm/article/viewFile/4810/4421.

[4] Kent M. Vegetation Description and Data Analysis: A Practical Approach. John Wiley Sons; 2011.

[5] Londo G. The decimal scale for relev6s of permanent quadrats. Vegetatio. 1976;33:61-64. DOI: 10.1007/BF00055300.

[6] Van der Maarel E. Transformation of cover-abundance values in phytosociology and its effects on community similarity. Vegetatio. 1979;39(2):97-114. DOI: 10.1007/BF00052021.

[7] Van der Maarel E. Transformation of cover abundance values for appropriate numerical treatment. Alternatives to the proposals by Podani. J Veg Sci. 2007;18(5):767-770. DOI: 10.1111/j.1654-1103.2007.tb02592.x.

[8] Podani J. Braun-Blanquet's legacy and data analysis in vegetation science. J Veg Sci. 2006;17:113-117. DOI: 10.1111/j.1654-1103.2006.tb02429.x.

[9] Domin K. Problémy a metody rostlinné sociologie a jejich použiti pro výzkum lučnich a pastvinǽch porosto Republiky Ceskoslovenské [Problems and methods of plant sociology and their application for the analysis of meadows and pastures]. Publ. Min. Zem. 1923;39:1-376. 
[10] Currall JEP. A transformation of the Domin scale. Vegetatio. 1987;72(2):81-87. DOI: 10.1007/BF00044837.

[11] Doing Kraft H. L'analyse. des carrés permanents. (Analyses. Permanent quadrats). Acta Bot Neerl. 1954;3(3):421-424. DOI: 10.1111/j.1438-8677.1954.tb00307.x.

[12] Lepš J, Hadincová V. How reliable are our vegetation analyses? J Veg Sci. 1992;3:119-124. DOI: $10.2307 / 3236006$

[13] Klimeš L. Scale-dependent variation in visual estimates of grassland plant cover. J Veg Sci. 2003;14:815-821. DOI: 10.1111/j.1654-1103.2003.tb02214.x.

[14] Górecki A, Kozłowski J, Gębczyński M. Ćwiczenia z ekologii. Podręcznik dla studentów biologii ogólnej i biologii środowiskowej [Ecology excercises. Handbook for student of basic ecology and environmental biology]. Kraków, Białystok: Uniwersytet Jagielloński, Filia Uniwersytetu Warszawskiego; 1987.

[15] Oksanen J, Blanchet FG, Friendly M, Kindt R, Legendre P, McGlinn D, et al. vegan: Community Ecology Package. R package version 2.4-1. 2016. https://CRAN.R-project.org/package=vegan.

[16] R Core Team. R: A language and environment for statistical computing. R Foundation for Statistical Computing. Vienna. Austria: 2016. URL https://www.R-project.org/.

[17] Baselga A. Partitioning the turnover and nestedness components of beta diversity. Global Ecol Biogeogr. 2010;19:134-143. DOI: 10.1111/j.1466-8238.2009.00490.x.

[18] Baselga A. The relationship between species replacement, dissimilarity derived from nestedness, and nestedness. Global Ecol Biogeogr. 2012;21:1223-1232. DOI: 10.1111/j.1466-8238.2011.00756.x.

[19] Roe CM, Parker GC, Korsten AC, Lister CJ, Weatherall SB, Lodge L, et al. Small-scale spatial autocorrelation in plant communities: the effects of spatial grain and measure of abundance, with an improved sampling scheme. J Veg Sci. 2012;23(3):471-482. DOI: 10.1111/j.1654-1103.2011.01375.x.

[20] Hurlbert SH. Pseudoreplication and the design of ecological field experiments. Ecol Monogr. 1984;54(2):187-211. DOI: 10.2307/1942661.

[21] Beatty SW, Stone EL. The variety of soil microsites created by tree falls. Can J Forest Res. 1986;16(3):539-548. DOI: 10.1139/x86-094.

[22] Klama H. Distribution patterns of liverworts in natural forest communities (Białowieża Primeval Forest, NE Poland). Bielsko-Biała: Wyd. Akad. Techniczno-Humanistycznej; 2002.

[23] Drew WB. Studies on the use of the point-quadrat method of botanical analysis of mixed pasture vegetation. J Agr Res. 1944;69(7):289-297.

[24] Jennings SB, Brown ND, Sheil D. Assessing forest canopies and understorey illumination: canopy closure, canopy cover and other measures. Forestry. 1999;72(1):59-74. DOI: 10.1093/forestry/72.1.59.

[25] Chmura D, Salachna A, Sierka E. Porównanie oceny zwarcia drzewostanu za pomocą metody wizualnej i zwarciomierza [Comparison of visual estimation of the canopy cover with the canopyscope assessment]. Sylwan. 2016;160(6):475-481. https://sylwan.lasy.gov.pl.

\title{
BŁĘDY W OSZACOWANIU POKRYCIA ROŚLIN W KONTEKŚCIE NAUCZANIA FITOSOCJOLOGII
}

\author{
Instytut Ochrony i Inżynierii Środowiska, Akademia Techniczno-Humanistyczna w Bielsku-Białej
}

\begin{abstract}
Abstrakt: W naukach o roślinności, w tym fitosocjologii, wizualne oszacowanie pokrycia roślin i metoda punktowa należą do częstych metod terenowych służących do odnotowania składu gatunkowego roślin i ich liczebności. Porównano dwie metody: skalę Braun-Blanqueta i metodę punktową z użyciem mostka (koziołka) Levy'ego. Grupa studentów na pięciu powierzchniach w lesie grądowym Tilio-Carpinetum przeprowadziła badania terenowe za pomocą obydwu metod. Stwierdzono duże rozbieżności między dwiema metodami w liczbie zaobserwowanych gatunków. Średnie liczby gatunków wynosiły 13,4 i 31,2 odpowiednio dla metody punktowej i metody Braun-Blanqueta, natomiast wartości pokrycia uzyskane obiema metodami są istotnie skorelowane. Można wnioskować, że metoda punktowa nie nadaje się do badania runa leśnego. Można ją łączyć z innymi metodami. Ze względu na wielość powtarzanych pomiarów może być pomocna w uczeniu się rozpoznawania gatunków.
\end{abstract}

Słowa kluczowe: wzrokowa ocena pokrycia, błąd w próbkowaniu, pseudowymiana gatunkowa 